\title{
Tracing and Dating Young Ground Water
}

Data on concentrations of environmental tracers, such as chlorofluorocarbons (CFCs), tritium $\left({ }^{3} \mathrm{H}\right)$, and other chemical and isotopic substances in ground water, can be used to trace the flow of young water (water recharged within the past 50 years) and to determine the time elapsed since recharge. Information about the age of ground water can be used to define recharge rates, refine hydrologic models of ground-water systems, predict contamination potential, and estimate the time needed to flush contaminants from ground-water systems. CFCs also can be used to trace seepage from rivers into ground-water systems, provide diagnostic tools for detection and early warning of leakage from landfills and septic tanks, and to assess susceptibility of water-supply wells to contamination from near-surface sources.

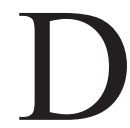
uring the past 50 years, human activities have released an array of chemical and isotopic substances to the atmosphere. In the atmosphere, these substances have mixed and spread worldwide. These atmospheric substances, such as tritium $\left({ }^{3} \mathrm{H}\right)$ in water vapor from detonation of nuclear bombs in the 1950s and early 1960s, and chlorofluorocarbons (CFCs) from refrigeration and other uses from the 1950s through the 1980s, dissolve in precipitation, become incorporated in the Earth's hydrologic cycle, and can be found in ground water that has been recharged within the past 50 years. The detection of chlorofluorocarbons and tritium in ground water provides valuable information that can be used for dating and tracing young ground watertechniques that help water-resources managers develop management strategies for shallow ground-water systems.

\section{Young ground water in shallow ground-water systems}

Young ground water is typically found at depths from 0 to 100 feet in unconsolidated sediments and at depths up to 1000 feet in fractured-rock systems. Shallow ground-water systems are commonly used for drinking water sources and they make up a large part of the baseflow in rivers and lakes. However, shallow ground-water supplies are generally young (recently recharged) and, because there has been a wide variety of man-made pollutants pro- duced in the 20th century, are more susceptible to contamination than deeper ground water. Information about groundwater age can be used to determine recharge rates and refine hydrologic models of ground-water systems (Reilly and others, 1994; Szabo and others, 1996) and thus to predict the contamination potential and estimate the time needed to flush contaminants through a ground-water system.

The 0- to 50-year time scale is particularly relevant to environmentally sensitive shallow ground-water systems. Prior to the late $1980 \mathrm{~s}$, however, there were no reliable means of dating ground water recharged during this time scale and, until recently, none of those methods were considered practical for use in establishing regional patterns. In the early 1990s, USGS scientists (Busenberg and Plummer, 1992) developed a method to date ground water on the basis of chlorofluorocarbon (CFC) content of the water that is practical, costeffective, and applicable to most shallow ground-water systems.

\section{Sampling for tracers}

The feasibility of using CFCs as tracers of recent recharge and indicators of groundwater age was first recognized in the 1970s (see Plummer and Busenberg, 1997 and references therein). CFCs have been increasingly used in oceanic studies since the late 1970 s as tracers of oceanic circulation, ventilation, and mixing processes. USGS scientists (Busenberg and Plummer, 1992) adapted analytical procedures developed by the oceanographic scientific community for ground-water studies and designed sampling equipment and procedures for collection and preservation of water samples in the field. Water samples for CFC analysis are now routinely collected from domestic, irrigation, monitoring, and municipal wells, and from springs. A closed path is established

USGS Hydrologist collects a water sample for CFC analyses from a domestic well in south-central Idaho.

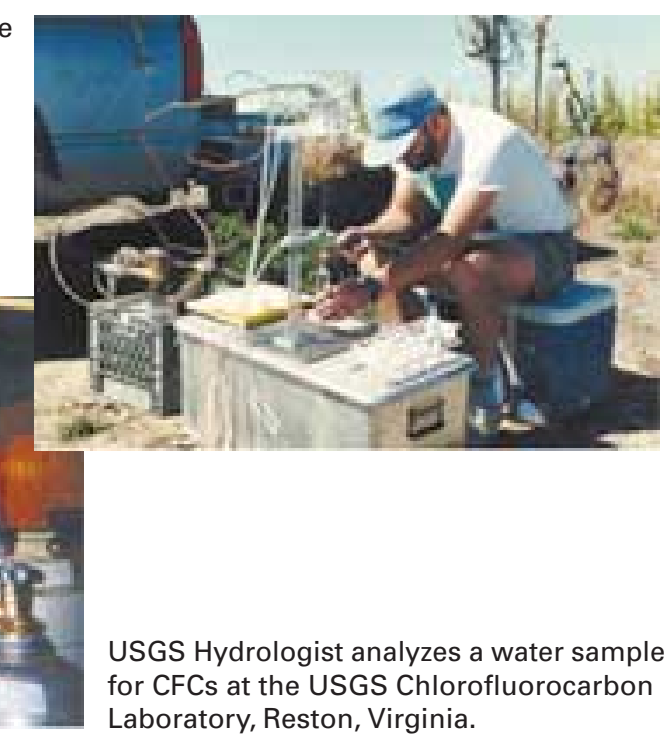


Chlorofluorocarbons are stable, synthetic organic compounds that were developed in the early 1930 s as safe alternatives to ammonia and sulfur dioxide in refrigeration and have been used in a wide range of industrial and refrigerant applications. Production of CFC-12 (dichlorodifluoromethane, $\mathrm{CF}_{2} \mathrm{Cl}_{2}$ ) began in 1931, followed by CFC-11 (trichlorofluoromethane, $\mathrm{CFCl}_{3}$ ) in 1936, and then by many other CFC compounds, most notably CFC-113 (trichlorotrifluoroethane, $\mathrm{C}_{2} \mathrm{~F}_{3} \mathrm{Cl}_{3}$ ). CFC-11 and CFC-12 were used as coolants in air conditioning and refrigeration, blowing agents in foams, insulation, and packing materials, propellants in aerosol cans, and as solvents. CFC-113 has been used primarily by the electronics industry in semiconductor chip manufacturing, in vapor degreasing and cold immersion cleaning of microelectronic components, and surface cleaning. Probably better known to the public as Freon ${ }^{\mathrm{TM}}$, CFCs are nontoxic, nonflammable and noncarcinogenic, but they contribute to ozone depletion. Therefore in 1987, 37 nations signed an agreement to limit release of CFCs and to halve CFC emissions by 2000. This agreement, the Montreal Protocol on Substances That Deplete the Ozone Layer, was strengthened in 1990 and again in 1992 when 1996 was established as the cut-off date for CFC production in industrialized countries. Production of CFCs ceased in the United States as of January 1, 1996, under the Clean Air Act. Current estimates of the atmospheric lifetimes of CFC-11, CFC-12, and CFC- 113 are about 45,87 , and 100 years, respectively.

between the well or pump to a valve system that is used to fill glass ampoules with water, creating a headspace with CFC-free, ultra-pure nitrogen gas. The samples are then transported to the U.S. Nuclear Regulatory Commission-licensed USGS laboratory for analysis of CFC content by gas chromatography to a detection limit of about 0.3 picograms per kilo$\operatorname{gram}(0.3 \mathrm{pg} / \mathrm{kg})$ of water, which is equivalent to $0.3 \times 10^{-12}$ grams per kilogram, or 0.3 parts per quadrillion.

\section{Determining ground-water ages}

Ground-water dating with CFC-11, CFC12 and CFC-113 is possible because

(1) their amounts in the atmosphere over the past 50 years have been reconstructed, (2) their solubilities in water are known,

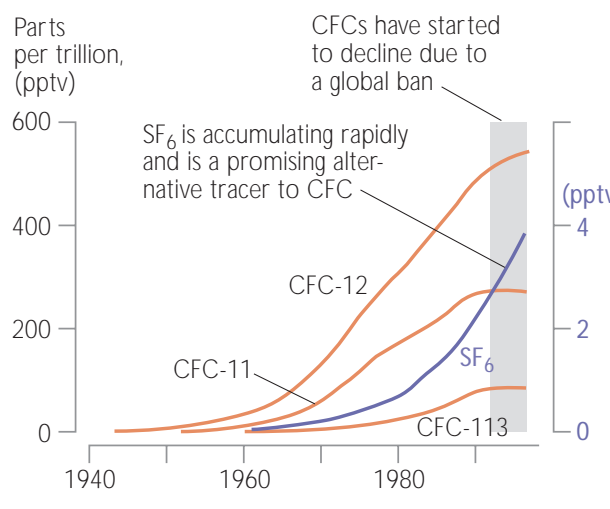

CFCs and sulfur hexafluoride $\left(\mathrm{SF}_{6}\right)$ concentrations (mixing ratios) for air over North America during the last 50 years. and (3) concentrations in air and young water are high enough that they can be measured. Age is determined from CFCs by relating their measured concentrations in ground water back to known historical atmospheric concentrations and/or to calculated concentrations expected in water in equilibrium with air. As with any environmental tracer, age applies to the date of introduction of the chemical substance into the water, and not to the water itself. The accuracy of the determined age depends in part on how perfectly the CFCs are transported with the water. Chemical processes, such as microbial degradation and sorption during transit, can also affect the concentration of CFCs and other compounds used in dating. For this reason, the term "age" is normally qualified with the word "model" or "apparent," that is, "model age" or "apparent age."

USGS scientists have investigated some of the most important factors that can affect $\mathrm{CFC}$ concentrations in ground water and the resulting age interpretations (Busenberg and Plummer, 1992; Plummer and others, 1993; Dunkle and others, 1993; Ekwurzel and others, 1994; Cook and others, 1995; Plummer and others 1998a, 1998b; Plummer and Busenberg, 1999). These include (1) uncertainty of the temperature at the water table during recharge, (2) entrapment of excess air during recharge, (3) uncertainty in recharge elevation, (4) thickness of the unsaturated zone, (5) effect of urban air


Concentrations of CFC-11, CFC-12, and CFC113 in water recharged in equilibrium with air between the years 1940 and 2000 at temperatures of 5 to $25^{\circ} \mathrm{C}$. The CFC analysis determined that concentrations of CFC-11, CFC-12 and CFC-113 were 493, 203, and 28 $\mathrm{pg} / \mathrm{kg}$ in the water sample to be dated. The recharge temperature of $10^{\circ} \mathrm{C}$ was determined from analysis of dissolved nitrogen and argon in the water sample.

where $\mathrm{CFC}$ values may exceed regional values, (6) contamination from a specific local source, (7) microbial degradation (in anaerobic environments), (8) sorption onto organic and mineral surfaces, and (9) mixing of younger and older water in a well. Because of the effect of these factors on CFC concentration, collection of additional data is often needed to determine the apparent age of ground water. For example, measurements of concentrations of dissolved gases, such as dissolved oxygen, help to define the potential for microbial degradation. Measurements of dissolved methane are useful in recognizing environments where all three $\mathrm{CFCs}$ can be degraded. Measurements of dissolved nitrogen and argon can be used to help determine recharge temperature and excess air and to recognize environments undergoing denitrification.

\section{Other chemical dating tools}

Tritium (half-life 12.4 years) provides another useful tracer of young ground water. Although it is difficult to evaluate age 
information from tritium data alone, age commonly can be reliably determined from data on tritium $\left({ }^{3} \mathrm{H}\right)$ and its decay product, helium-3 $\left({ }^{3} \mathrm{He}\right)$. The ${ }^{3} \mathrm{H} /{ }^{3} \mathrm{He}$ age is based on a calculation that determines the amount of ${ }^{3} \mathrm{He}$ derived from radioactive decay of ${ }^{3} \mathrm{H}$ in the water. Several conditions are necessary to solve the calculation and interpret the age: (1) The sample must contain detectable ${ }^{3} \mathrm{H}$ (greater than approximately 0.5 tritium unit, or TU, which is defined as one ${ }^{3} \mathrm{H}$ atom in $10^{18}$ hydrogen atoms) and (2) if the sample contains terrigenic helium from the Earth's crust and mantle sources, the relative abundances of helium-3 and helium-4 isotopes in the terrigenic helium must be known, and data on dissolved neon concentrations in the sample are needed to help determine how much helium-3 is derived from tritium decay. Water samples for ${ }^{3} \mathrm{H} /{ }^{3} \mathrm{He}$ age determination can be collected more easily than those for CFC determination, but are more difficult and costly to analyze than CFC samples.

Krypton-85 $\left({ }^{85} \mathrm{Kr}\right)$ has also been used to date ground water. The source for atmospheric input of ${ }^{85} \mathrm{Kr}$ is reprocessing of fuel rods from nuclear reactors. Because of difficulties in collection and analysis, ${ }^{85} \mathrm{Kr}$ is not yet a practical dating tool for ground-water studies. In CFC-contaminated environments, or environments where methane is forming from microbial degradation of organic matter, noble-gas dating techniques such as those based on ${ }^{3} \mathrm{H} /{ }^{3} \mathrm{He}$ and ${ }^{85} \mathrm{Kr}$ measurements may be the only techniques for dating. However, because of their low detection limit and low sensitivity to hydrodynamic dispersion, CFCs can be more reliable than ${ }^{3} \mathrm{H} /{ }^{3} \mathrm{He}$ and ${ }^{85} \mathrm{Kr}$ dating for waters recharged in the late $1940 \mathrm{~s}$ and $1950 \mathrm{~s}$.

\section{Seeking alternatives to CFC dating}

Alternatives to using CFCs in dating ground water will clearly be needed as atmospheric CFC concentrations continue to fall. The use of sulfur hexafluoride $\left(\mathrm{SF}_{6}\right)$ appears to be a promising technique and is under investigation by USGS scientists (Busenberg and Plummer, 1997; Plummer and Busenberg, 1999). Industrial production of $\mathrm{SF}_{6}$ began in 1953 with the introduction of gas-filled high-voltage electrical switches. $\mathrm{SF}_{6}$ is extremely stable and is accumulating rapidly in the atmosphere. The historical atmospheric mixing ratio of $\mathrm{SF}_{6}$ is being reconstructed from production records, archived air samples, and atmospheric measurements, and retrieved from concentrations measured in seawater and in previously-dated ground water. A preliminary reconstruction has been made of northern-hemisphere $\mathrm{SF}_{6}$ mixing ratios (figure far left). As atmospheric CFC concentrations fall, an even more sensitive dating tool will be the ratio of $\mathrm{SF}_{6}$ to, for example, $\mathrm{CFC}-12$. Although $\mathrm{SF}_{6}$ is almost entirely of human origin, there is likely a natural, igneous source of $\mathrm{SF}_{6}$ that will complicate dating in some environments. USGS scientists have successfully used $\mathrm{SF}_{6}$ to date shallow ground water on the Delmarva Peninsula, Maryland, and water from springs in the Blue Ridge Mountains of Virginia with $\mathrm{SF}_{6}$.

\section{Additional comments and case studies}

For best results, the apparent age should be determined using multiple dating techniques because each dating technique has limitations. CFC dating is best suited for ground water in relatively rural environments where localized contamination, such as that from septic systems, sewage effluent, landfills, or urban runoff, can contain CFC concentrations in excess of that of atmospheric sources. The dating method appears to work well in shallow, aerobic, sand aquifers that are low in particulate organic matter and the results can be accurate within 2-3 years in this type of environment. Even where there are problems with CFC dating of ground water, the presence of CFCs indicates that the water sample contains at least some post1940s water, making CFCs useful as tracers of recent recharge. Where CFC and
${ }^{3} \mathrm{H} /{ }^{3} \mathrm{He}$ ages agree, or where all three CFCs indicate similar ages, considerable confidence can be placed in the apparent age.

Delmarva Peninsula Results from the determination of CFCs in some agricultural areas on the Delmarva Peninsula of Maryland and Virginia indicate that water recharged since the early 1970s exceeds the U.S. Environmental Protection Agency drinking water Maximum Contaminant Level (MCL) for nitrate of $10 \mathrm{mg} / \mathrm{L}$ (as $\mathrm{N}$ ), while water recharged prior to the early 1970 s, before the heavy use of nitrogen fertilizers, does not exceed the MCL (Dunkle and others, 1992; Ekwurzel and others, 1994; Böhlke and Denver, 1995). Nitrate concentrations in ground water under woodlands were low, whereas ground water recharged under agricultural fields had nitrate concentrations that exceeded the MCL. CFC concentrations indicate that ground water now discharging to streams that drain agricultural areas of the Delmarva and then flow into the Chesapeake Bay or the Atlantic Ocean, was recharged in nearby fields in the 1960s and 1970s (Böhlke and Denver, 1995; Focazio and others, 1998). Thus, even if the application of nitrogen fertilizers to the fields stopped today, streams, rivers, and estuaries can be expected to receive increasing amounts of nitrate from ground-water discharge until the contaminated water is flushed through the system (Modica and others, 1998); up to 30 years may be needed to flush the high-nitrate water present in several small agricultural watersheds.

Central Oklahoma Water discharged from deep (400 to 800 feet) municipal supply wells in the central Oklahoma aquifer contains CFCs (Busenberg and

CFCs and nitrate concentrations were measured between June 1989 and January 1990 on a section of the Delmarva Peninsula, in the Fairmount watershed. Ground-water dating reveals a pattern of high nitrate concentrations moving slowly toward the estuary.

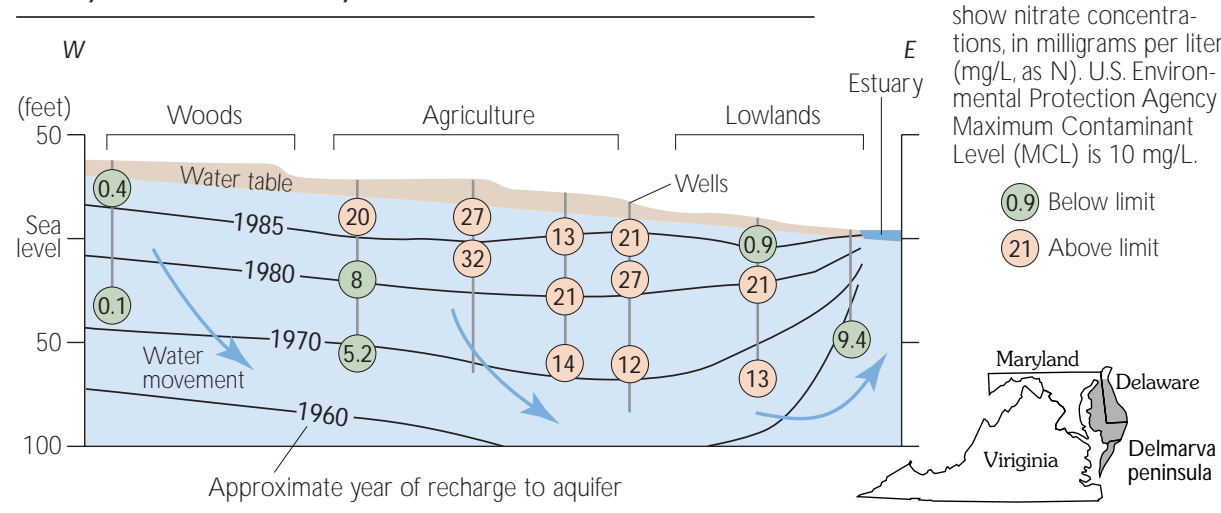

N umbers within circles show nitrate concentra (in milligrams per liter mental Protection A gency Maximum Contaminant (0.9) Below limit (21) Above limit Approximate year of recharge to aquifer peninsula 
Plummer, 1992). This unexpected finding indicated that shallow ground water was being mixed with deep, older water during pumping. In this case, CFCs were a valuable tracer for testing hydraulic seals of municipal water wells and their susceptibility to contamination. River water downstream from outfalls of sewage treatment plants in central Oklahoma contained very high concentrations of CFCs, which were also found in shallow ground water in the alluvium and terrace system near rivers.

Idaho At the Idaho National Engineering and Environmental Laboratory (INEEL), the ground-water $\mathrm{CFC}$ concentrations were found to be in equilibrium with the shallow soil air, rather than air from the deeper unsaturated zone (Busenberg and others, 1993). This indicates that these waters passed rapidly through the unsaturated zone to the water table, rather than recharging by slow percolation. Temperatures derived from gas solubilities in ground water suggest that the aquifer is recharged locally. Ground-water velocities on the order of 6 to 24 feet per day were found in the Snake River Plain aquifer beneath the INEEL. USGS scientists (Busenberg and others, 1998) have also used CFCs in water and unsaturated zone air to trace the movement of organic waste plumes at INEEL.
Nevada Measurements of CFCs in unsaturated-zone air along the crest of Yucca Mountain, Nevada, a potential site for a high-level radioactive waste repository, show that the residence time of shallow advecting gas is less than 5 years (Thorstenson and others, 1998). Previous estimates based on carbon-14 measurements of unsaturated-zone carbon dioxide indicated a residence time of less than 40 years. In addition to decreasing the estimated travel time by an order of magnitude, the CFC data allowed gas circulation patterns in the mountain to be identified and quantified. These results are highly relevant to issues pertaining to isolation of possible repository-generated radioactive ${ }^{14} \mathrm{CO}_{2}$.

Georgia CFCs were used to trace and date leakage of river water through sinkholes into the Upper Floridan aquifer near Valdosta, Georgia (Plummer and others, 1998a, 1998b). The ages of the young-water fractions in the Upper Floridan aquifer were mapped throughout the Valdosta area. The dating indicates that few domestic and municipal supply wells produce river-water fractions that are younger than 5 years, and most river water sampled was likely recharged through the sinkholes during the past 20 to 30 years. Ground-water velocities ranged from 1 to 27 feet per day.

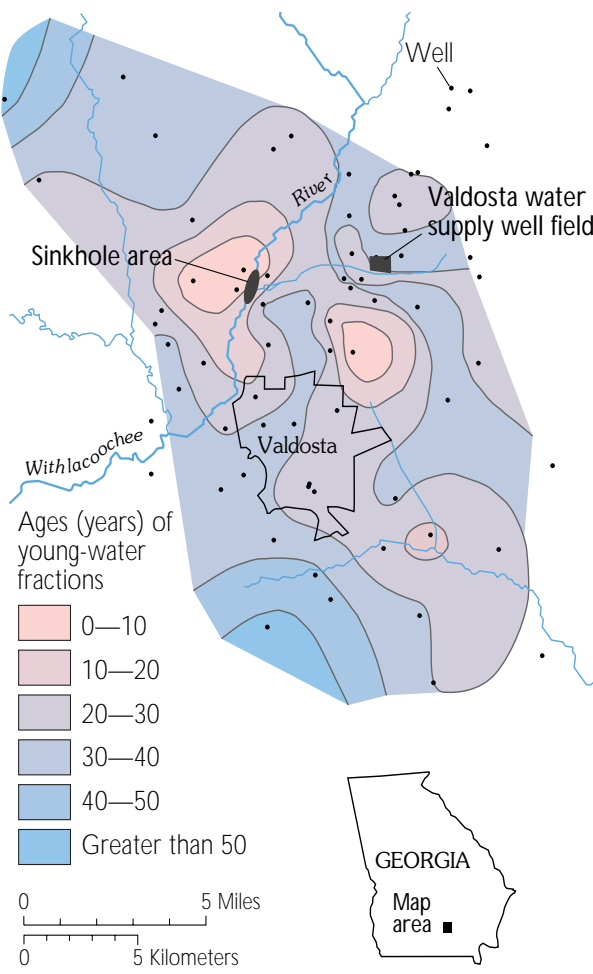

CFCs were used to trace and date water in the karst aquifer near Valdosta, Georgia.

Ground-water dating at Valdosta helps define the susceptibility to contamination of the ground-water resources.

-L. Niel Plummer and Linda C. Friedman

\section{REFERENCES}

Böhlke, J.K., and Denver, J.M., 1995, Combined use of groundwater dating, chemical, and isotopic analyses to resolve the history and fate of nitrate contamination in two agricultural watersheds, Atlantic coastal plain, Maryland: Water Resources Research, v. 31, p. 2319-2339.

Busenberg, Eurybiades, and Plummer, L.N., 1992, Use of chlorofluorocarbons $\left(\mathrm{CCl}_{3} \mathrm{~F}\right.$ and $\left.\mathrm{CCl}_{2} \mathrm{~F}_{2}\right)$ as hydrologic tracers and age-dating tools: Example-The alluvium and terrace system of central Oklahoma: Water Resources Research, v. 28, 2257-2284.

Busenberg, Eurybiades, and Plummer, L.N., 1997, Use of sulfur hexafluoride as a dating tool and as a tracer of igneous and volcanic fluids in ground water (abs.): Geological Society of America, Salt Lake City, 1997, Abstracts and Programs, v. 29(6), p. A-78.

Busenberg, Eurybiades, Plummer, L.N., Bartholomay, R.C., and Wayland, J.E., 1999, Chlorofluorocarbons, sulfur hexafluoride, and dissolved permanent gases in ground water from selected sites in and near the Idaho National Engineering and Environmental Laboratory, Idaho, 1994-97: U.S. Geological Survey Open-File Report 98-274, 72 p.

Busenberg, Eurybiades, Weeks, E.P., Plummer, L.N., and Bartholomay, R.C., 1993, Age dating ground water by use of chlorofluorocarbons $\left(\mathrm{CCl}_{3} \mathrm{~F}\right.$ and $\left.\mathrm{CCl}_{2} \mathrm{~F}_{2}\right)$, and distribution of chlorofluorocarbons in the unsaturated zone, Snake River Plain aquifer, Idaho National Engineering Laboratory, Idaho: U.S. Geological Survey Water-Resources Investigations Report 93-4054, 47 p.

Cook, P.G., Solomon, D.K., Plummer, L.N., Busenberg, Eurybiades, and Schiff, S.L.,1995, Chlorofluorocarbons as tracers of groundwater transport processes in a shallow, silty sand aquifer: Water Resources Research, v. 31, p. 425-434.

Dunkle, S.A., Plummer, L.N., Busenberg, Eurybiades,

Phillips, P.J., Denver, J.M., Hamilton, P.A., Michel, R.L. and Coplen, T.B., 1993, Chlorofluorocarbons $\left(\mathrm{CCl}_{3} \mathrm{~F}\right.$ and
$\mathrm{CCl}_{2} \mathrm{~F}_{2}$ ) as dating tools and hydrologic tracers in shallow ground water of the Delmarva Peninsula, Atlantic Coastal Plain, United States: Water Resources Research, v. 29, p. 3837-3860.

Ekwurzel, Brenda, Schlosser, Peter, Smethie, W., Jr., Plummer, L.N., Busenberg, Eurybiades, Michel, R.L., Weppernig, Ralf, and, Stute, M., 1994, Dating of shallow groundwater: Comparison of the transient tracers ${ }^{3} \mathrm{H} /{ }^{3} \mathrm{He}$, chlorofluorocarbons and ${ }^{85} \mathrm{Kr}$ : Water Resources Research, v. 30 , p. $1693-1708$.

Focazio, M.J., Plummer, L.N., Bohlke, J.K., Busenberg, Eurybiades, Bachman, L.J., and Powers, D.S., 1998, Preliminary estimates of residence times and apparent ages of ground water in the Chesapeake Bay watershed and waterquality data from a survey of springs: U.S. Geological Survey Water-Resources Investigations Report 97-4225, 75 p.

Modica, Edward, Buxton, H.T., and Plummer, L.N., 1998, Evaluating the source and residence times of ground-water seepage to headwaters streams, New Jersey Coastal Plain: Water Resources Res., v. 34, p. 2797-2810.

Plummer, L.N. and Busenberg Eurybiades, 1999, Chlorofluorocarbons in P. Cook and A. Herczeg, eds., Environmental Tracers in Subsurface Hydrology: Kluwer Academic Press, in press.

Plummer, L.N., McConnell, J.B., Busenberg, Eurybiades, Drenkard, Stefan, Schlosser, Peter, and Michel, R.L., 1998a, Flow of river water into a karstic limestone aquifer, 1. Tracing the young fraction in groundwater mixtures in the Upper Floridan aquifer near Valdosta, Georgia: Applied Geochemistry, v. 13, p. 995-1015.

Plummer, L.N., Busenberg, Eurybiades, Drenkard, Stefan, Schlosser, Peter, McConnell, J.B., Michel, R.L., Ekwurzel, Brenda, and Weppernig, Ralf, 1998b, Flow of river water into a karstic limestone aquifer, 2. Dating the young fraction in groundwater mixtures in the Upper Floridan aquifer near Valdosta, Georgia: Applied Geochemistry, v. 13, p. 1017-1043.

Plummer, L.N., Michel, R.L., Thurman, E.M., and Glynn, P.D., 1993, Environmental tracers for age-dating young ground water: Alley, W.M., ed., Regional Ground-water Quality: Van Nostrand Reinhold, p. 255-294.

Reilly, T.E., Plummer, L.N., Phillips, P.J., and Busenberg, Eurybiades 1994, Estimation and corroboration of shallow ground-water flow paths and travel times by environmental tracer and hydraulic analyses - A case study near Locust Grove, Maryland: Water Resources Research, v. 30, p. 421-433.

Szabo, Z., Rice, D.E., Plummer, L.N., Busenberg, Eurybiades, Drenkard, Stefan, and Schlosser, Peter, 1996, Age-dating of shallow groundwater with chlorofluorocarbons, tritium/helium 3, and flow path analysis, southern New Jersey coastal plain: Water Resources Research, v. 32, p. $1023-1038$

Thorstenson, D.C., Weeks, E.P., Haas, H., Busenberg, Eurybiades, Plummer, L.N., and Peters, C.A., 1998, Chemistry of unsaturated zone gases sampled in open boreholes at the crest of Yucca Mountain, Nevada: Data and basic concepts of chemical and physical processes in the mountain: Water Resources Research, v. 34, p.1507-1529.

For additional information, see http://water.usgs.gov/lab/cfc/ or contact:

Niel Plummer (email: nplummer@usgs.gov) U.S. Geological Survey

12201 Sunrise Valley Drive, MS 432

Reston, VA 20192 